\title{
PENGARUH PENGGUNAAN METODE ROLE PLAYING TERHADAP MINAT BELAJAR SISWA KELAS X PADA MATERI VIRUS DI SMA AZHARYAH PALEMBANG
}

\author{
Munir $^{1)}$ Awalul Fatiqin'2), Ira Kendi ${ }^{3)}$ \\ 1) 2) 3) Universitas Islảm Negeri (UIN) Raden Fatah Palembang \\ email: kendiira@yahoo.co.id
}

Diterima 2 Februari 2017, Disetujui 8 Maret 2017

\begin{abstract}
A learning activity that did not correspond with the interest will generated unfavorable achievement. It can be said that with appropriate learning methods can lead to student interst. In learning process we need to caused a learning interest to the students. But in the real class a lot of teachers finds obtacles, because the lack of variations in learning method. Therefore the formulation of the problems is there any affection towards the use of role playing method in student learning interest on tenth grade student of SMA Azharyah palembang, this study aims to determine the effect of the use of the role playing towards the student learning interest of class X on virus material in SMA Azharyah Palembang . this research was done in august until semptember 2016 in SMA Azharyah Palembang. The population of this research was all of X student class of SMA Azharyah Palembang which is divided inti 2 classes and 30 students in average. X1 as a experiment class and X2 as a control class, sampling was done by used sampling jenuh technique. The research was used quantitative research method. The design was used in this research is true experimental design in form of posstest-only control design. To se the interest in students learning is done by using questionnaires and observation sheets. And to measure the effect of role playing method to student learning interst is using t-test. The result show that the learning interst in experiment class in high category was $33 \%$, medium $47 \%$ and low $20 \%$. Meanwhile in control class in high category was $20 \%$, medium $50 \%$ and low $30 \%$ this shows that the experimental class student learning interest is higher compared to the control class. Furthermore there is an influence on students learning interest. Obtained $t$ hitung $=11,75$ then compared with $t$ table $=1,671$. So the result showed that $t$ hitung $>t$ table. Thus Ha accepted.
\end{abstract}

Key words: method role playing, student learning interest.

\section{PENDAHULUAN}

Pembelajaran Biologi di SMA banyak mengalami kesulitan. Salah satunya dapat disebabkan oleh karakteristik materi yang terdapat pada pelajaran Biologi tersebut. Banyak siswa mengalami kesulitan untuk memahami Biologi terutama konsep fisiologis yang abstrak dan membutuhkan banyak hafalan (Lazarowitz, 1992 dalam Widarti dkk, 2013). Michael menyatakan terdapat beberapa hal yang dapat menyebabkan materi fisiologis dianggap sulit, yaitu karakteristik materi Biologi yang akan dipelajari, cara mengajarkan materi, dan modal awal siswa yang akan mempelajari materi (Widarti dkk, 2013).

Aktivitas belajar bagi setiap individu tidak selamanya dapat berlangsung secara wajar. Kadang-kadang lancar, kadangkadang tidak, kadang-kadang dapat cepat menangkap apa yang dipelajari, kadangkadang terasa amat sulit. Semangat siswa terkadang tinggi, tetapi terkadang juga sulit untuk mengadakan konsentrasi. Ada beberapa ahli pesimis untuk menyebutkan penyebab kesulitan belajar. Fenomena kesulitan belajar seorang siswa biasanya tampak jelas dari menurunnya kinerja akademik atau prestasi belajarnya. Kesulitan belajar juga dapat dibuktikan dengan munculnya kelainan perilaku (misbehavior) siswa seperti kesukaan berteriak-berteriak di dalam kelas, mengusik teman, berkelahi, sering bolos, dan sering minggat dari sekolah (Amilda dan Mardiah, 2012). 
Tidak adanya minat seseorang anak terhadap suatu pelajaran akan timbul kesulitan belajar. Belajar yang tidak ada minatnya mungkin tidak sesuai dengan bakatnya, tidak sesuai dengan kebutuhan, tidak sesuai dengan kecakapan, tidak sesuai dengan tipe-tipe khusus anak banyak menimbulkan problema pada dirinya. Karena itu pelajaran pun tidak pernah terjadi proses dalam otak, akibatnya timbul kesulitan. Ada tidaknya minat terhadap sesuatu pelajaran dapat dilihat dari cara anak mengikuti pelajaran, lengkap tidaknya catatan, memperhatikan garis miring tidaknya dalam pelajaran itu. Berdasarkan tanda-tanda itu seorang petugas diagnosis dapat menemukan apakah sebab kesulitan belajarnya disebabkan karena tidak adanya minat atau oleh sebab yang lain (Ahmadi, 2013).

Guru yang terampil dalam menggunakan metode pembelajaran akan relevan dengan komponen lainnya. Ada beberapa faktor yang harus diperhatikan dalam memilih metode mengajar, yaitu: tujuan yang hendak dicapai, materi pelajaran, media pelajaran, fasilitas guru, situasi, partisipasi, kebaikan dan kelemahan metode tertentu (Ramayulis, 2002).

Al-Qur' an sebagai sumber islam telah memerintahkan untuk memilih metode yang tepat dalam proses pembelajaran, seperti yang terdapat dalam Q.S An-Nahl: 125: yang artinya "Serulah (manusia) kepada jalan Tuhanmu dengan hikmah dan pelajaran yang baik dan bantahlah mereka dengan cara yang baik. Sesungguhnya Tuhanmu Dialah yang lebih mengetahui tentang siapa yang tersesat dari jalan- Nya dan Dialah yang lebih mengetahui orangorang yang mendapat petunjuk (Q.S AnNahl: 125).

Metode Role Playing sebagai salah satu metode pembelajaran yang dipilih dalam proses belajar mengajar bagi siswa. Siswa sangat antusias atau memperhatikan sekali terhadap pelajaran apabila pelajaran tersebut memang menyangkut kehidupan dia sehari-hari di lingkungan masyarakat. Pembelajaran berdasarkan pengalaman yang menyenangkan melalui pengembangan imajinasi dan penghayatan siswa (Abdurrahman, 2012). Guru sebagai perancang pembelajaran, merancang skenario yang akan diperankan oleh siswa, dengan demikian, kondisi belajar yang menyenangkan dan bermakna akan terwujud sehingga menyebabkan minat belajar siswa meningkat.

Alasan pemilihan pembelajaran Role Playing karena melalui teknik ini siswa dilibatkan secara aktif dalam situasi yang menyenangkan. Kejenuhan dan kebosanan siswa dapat teratasi melalui peran yang dimainkan. Minat siswa dalam pembelajaran biologi dapat terakomodasi saat bermain peran. Siswa tidak hanya aktif secara fisik, tetapi juga secara mental aktif yang meliputi kegiatan bertanya, berpendapat, menjawab pertanyaan dan menanggapi pendapat. Sesuai dengan pendapat dari Zuhairini, dkk., (1983) yang menyatakan bahwa metode bermain peran mampu menarik perhatian anak, sehingga suasana kelas semakin hidup, sehingga diharapkan Pembelajaran Role Playing dapat meningkatkan minat belajar siswa.

\section{METODE}

Tempat penelitian ini dilaksanakandi SMA Azharyah Palembang pada kelas X. Penelitian dilaksanakan pada tanggal 23 Agustus sampai tanggal 6 September 2016.

Subjek dalam penelitian ini adalah siswa SMA Azharyah Palembang kelas Xa dan $\mathrm{Xb}$. Siswa yang digunakan berjumlah 60.

Metode penelitian yang digunakan dalam penelitian ini adalah true eksperimental design tipe posttest-only control design. Instrumen yang digunakan dalam penelitian ini berupa angket minat belajar siswa.

Teknik penggumpulan data menggunakan observasi dan angket minat belajar siswa. Bentuk observasi yang digunakan adalah observasi partisipasi yaitu observasi yang dilakukan dengan pengamatan langsung pada objek penelitian. Skala yang digunakan yaitu skala likert. Setiap siswa diminta untuk 
menjawab setiap pernyataan dengan pilihan jawaban sangat setuju (SS), setuju (S), ragu-ragu (R), tidak setuju (ST), sangat tidak sejutu (STS) (Widoyo 2012).

Tabel 1. Hasil Posttest Kelas Eksperimen dan Kontrol

\begin{tabular}{ccc}
\hline Data & \multicolumn{2}{c}{ Kelas } \\
\cline { 2 - 3 } & Eksperimen & Kontrol \\
\hline Nilai Terendah & 60 & 40 \\
Nilai Tertinggi & 95 & 78 \\
Rata-Rata & 81,3 & 57,8 \\
Modus & 81,25 & 60,2 \\
Median & 77,35 & 57,2 \\
Simpangan Baku & 8,24 & 9,53 \\
Jumlah Siswa & 30 & 30 \\
\hline
\end{tabular}

Berdasarkan hasil posttest siswa kelas eksperimen dan kelas kontrol pada tabel di atas terdapat perbedaan minat belajar siswa yang diberi perlakuan dengan menggunakan metode role playing dan yang diajarkan dengan menggunakan metode konvensional, rata-rata minat belajar siswa di kelas eksperimen sebesar 81,3 sedangkan pada kelas kontrol ratarata skor angket sebesar 57,8 dapat dilihat pada Tabel 2.

Tabel 2.Perbedaan Posttest Minat Belajar Kelas Eksperimen Dan Kelas Kontrol

\begin{tabular}{ccccc}
\hline Kategori & $\begin{array}{c}\text { Kelas } \\
\text { Eksperi- } \\
\text { men }\end{array}$ & $\%$ & $\begin{array}{c}\text { Kelas } \\
\text { Kon- } \\
\text { trol }\end{array}$ & $\%$ \\
\hline Tinggi & 10 & $33 \%$ & 7 & $24 \%$ \\
Sedang & 14 & $47 \%$ & 13 & $43 \%$ \\
Rendah & 6 & $20 \%$ & 10 & $33 \%$ \\
Jumlah & 30 & $100 \%$ & 30 & $100 \%$ \\
\hline
\end{tabular}

Berdasarkan Tabel 2, kelas eksperimen dengan kategori minat yang tinggi terdapat 10 siswa dengan presentase $33 \%$, pada kategori minat yang sedang terdapat 14 siswa dengan presentase $47 \%$, dan yang tergolong minat yang rendah terdapat 6 orang siswa dengan presentase $20 \%$.. Sedangkan pada kelas kontrol kategori minat tertinggi terdapat 7 orang siswa dengan presentase $24 \%$, minat yang sedang terdapat 13 siswa dengan presentase $43 \%$, dan yang tergolong minat yang rendah sebanyak 10 siswa dengan presentase $33 \%$.

Tabel 2 menunjukkan bahwa rata-rata minat belajar siswa kelas eksperimen yang menggunakan metode role playing lebih besar dibandingkan rata-rata skor angket pada kelas kontrol dengan menggunakan metode konvensional.

Hasil minat belajar siswa kelas ekperimen dan kontrol yang telah dipresentasikan dapat dilihat pada grafik pada Gambar 1.

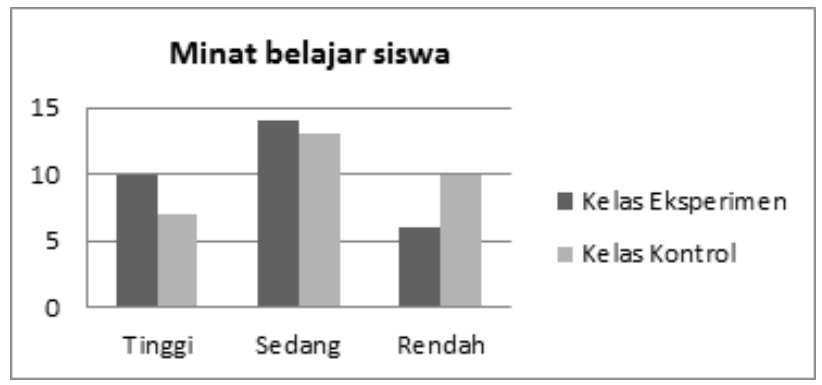

Gambar 1. Diagram Perbandingan Minat Siswa

\section{Uji Persyaratan Analisis Data}

Uji Normalitas Pada Kelas Eksperimen Menentukan normalitas data tersebut menggunakan rumus uji normalitas sebagai berikut:

$$
\begin{aligned}
& \mathrm{Km}=\frac{\overline{X-m o}}{s} \\
& \mathrm{Km}=\frac{81,3-81,25}{8,24} \\
& \mathrm{Km}=0,06
\end{aligned}
$$

Karena nilai kemencengan $\mathrm{Km}=$ 0,06 terletak antara -1 dan 1 maka data pada kelas tersebut dikatakan normal.

\section{Uji Normalitas Pada Kelas Kontrol}

$$
\begin{aligned}
& \mathrm{Km}=\frac{\overline{X-m o}}{S} \\
& \mathrm{Km}=\frac{57,8-760,2}{9,53} \\
& \mathrm{Km}=-0,25
\end{aligned}
$$

Berdasarkan nilai kemencengan $\mathrm{Km}$ $=-0,25$ terletak antara -1 dan 1 maka data pada kelas tersebut dikatakan normal.

Uji homogenitas data pada penelitian 

hipotesis:

angket tergolong homogen dengan

$\mathrm{H}_{\mathrm{a}}$ : Varians kelas eksperimen tidak sama dengan kelas kontrol

$\mathrm{H}_{0}$ : Varians kelas eksperimen sama dengan kelas kontrol

$$
\begin{aligned}
\mathrm{F} \quad & =\frac{\text { variansterbesar }}{\text { variansterkecil }} \\
& =\frac{9,53}{8,24} \quad=1,15
\end{aligned}
$$

Berdasarkan hasil pengujian yang dilakukan pada analisis data angket di dapat harga $\mathrm{F}_{\text {hitung }} 1,15$ selanjutnya $\mathrm{F}_{\text {hitung }}$ dibandingkan dengan $\mathrm{F}_{\text {tabel }}$ yaitu pada taraf signifikan 5\% yaitu 1,84, maka dapat disimpulkan bahwa $\left(\mathrm{F}_{\text {hitung }}<\mathrm{F}_{\text {tabel }}\right)$ hal ini berarti $\mathrm{H} 0$ diterima, dengan demikian menunjukkan bahwa kedua data kelompok tersebut homogen.

\section{Uji Hipotesis}

Menguji hipotesis pada penelitian ini digunakan uji-t pada taraf signifikan $5 \%$. Uji-t pada penelitian ini menggunakan rumus sebagai berikut:

$$
\begin{aligned}
\mathrm{t} & =\frac{X 1-X 2}{\sqrt{\frac{S 1^{2}}{n 1}+\frac{S 2^{2}}{n 2}}} \\
& =\frac{81,3-57,8}{\sqrt{\frac{8,24^{2}}{30}+\frac{9,53^{2}}{30}}} \\
& =\frac{23,5}{2,29} \\
& =11,75
\end{aligned}
$$

Berdasarkan hasil perhitungan menunjukkan bahwa nilai $t_{\text {hitung }}>t_{\text {tabel }}$ dengan nilai $11,75>1,672$ artinya $\mathrm{HO}$ ditolak dan Ha diterima dan dapat disimpulkan bahwa penggunaan metode role playing berpengaruh signifikan terhadap minat belajar siswa kelas X SMA Azharyah Palembang.

Berdasarkan hasil dari posttest yang telah diisi oleh siswa, metode role playing berpengaruh terhadap minat belajar siswa kelas X pada materi virus, terdapat perbedaan pada kelas eksperimen dan kelas kontrol. Kelas eksperimen rata-rata minat belajar siswa sebesar 81,3 sedangkan pada kelas kontrol rata-rata minat belajar siswa sebesar 57,8, dapat dilihat pada tabel 9.

Kelas eksperimen dengan menggunakan metode Role Playing siswa yang minatnya tinggi terdapat 10 siswa, minat yang sedang 14 siswa, dan minat yang rendah 6 orang. Kelas kontrol siswa yang minatnya tinggi terdapat 7 siswa, minat yang sedang 13 siswa, dan minat yang rendah 10 orang.

Terdapat pengaruh yang signifikan dan perbedaan yang nyata bahwa metode role playing dapat mempengaruhi minat belajar siswa, Terbukti bahwa pada kelas eksperimen siswa lebih bersemangat dalam belajar biologi pada materi virus. Siswa tidak kaku dan tidak malu serta sudah terbiasa mengikuti metoderole playing, siswa sepenuhnya aktif melaksanakan peran dan pemeranannya. Karena metode Role Playing menjadikan peserta didik terlibat aktif, sehingga pembelajaran tidak didominasi oleh pendidik. Selain itu, metode Role Playing juga memberikan suasana yang menyenangkan, sehingga siswa lebih antusias dalam mengikuti pembelajaran di kelas. Keaktivan siswa dalam suasana yang menyenangkan dalam proses pembelajaran, mengakibatkan pemahaman siswa dalam materi replikasi virus dan peranan virus meningkat sehingga minat belajar peserta didik meningkat. Seperti dikemukakan Arifin (2006) dalam Khaerani (2010) metode pembelajaran role playing merupakan salah satu alternatif yang layak dikembangkan untuk mengatasi masalah rendahnya mutu, proses, dan hasil pembelajaran.

Hasil pengamatan/observasi yang dilakukan dikelas eksperimen seperti pada lampiran 12. Rata-rata sikap senang siswa meningkat dari pertemuan I $77 \%$ sedangkan pada pertemuan ke II menjadi 90\%, disebabkan sikap senang peserta didik dapat diamati ketika siswa mengikuti pembelajaran dengan mengikuti permainan peran yang dilaksanakan, Menurut Hamdayana (2014) bahwa model bermain peran memiliki beberapa keunggulan yaitu: peserta didik bebas mengambil keputusan dan ekspresi secara 
utuh, permainan merupakan penemuan yang mudah dan dapat digunakan dalam situasi dan waktu yang berbeda, pendidik dapat mengevaluasi pemahaman setiap peserta didik melalui pengamatan pada saat melakukan permainan, permainan merupakan pengalaman belajar yang menyenangkan bagi anak.

Presentase sikap ingin tahu pada pertemuan pertama $68 \%$ menjadi $97 \%$ pada pertemuan kedua. Hal ini disebabkan karena sikap rasa ingin tahu dapat diamati saat siswa melakukan perannya dimana siswa mencari tahu materi virus yang diajarkan dengan menggunakan sumber lain seperti membuka internet dan melihat gambar atau video yang berhubungan dengan materi virus. Menurut Hamdayama (2014) model bermain peran merupakan suatu cara penguasaan baha-bahan pelajaran melalui imajinasi dan penghayatan peserta didik. Menurut Baroro (2011) dalam penelitiannya mengungkapkan bahwa dalam role playing peserta didik dituntuk menjadi pribadi yang imajinatif, mempunyai prakarasa, mempunyai minat yang luas, mandiri dalam berfikir, ingin tahu, penuh energi dan percaya diri.

Sikap perhatian dengan rata-rata pada pertemuan pertama $44 \%$ dan pada pertemuan kedua menjadi $82 \%$. Sikap perhatian diamati saat siswa yang lain memerankan perannya dan siswa yang lain sebagai observer memperhatikan dan mencatat hasil dari peragaan yang dilakukan oleh kelompok lain. Menurut pendapat Yamin (2005) bahwa model bermain peran adalah model yang melibatkan interaksi antara dua peserta didik atau lebih tentang suatu topik atau situasi. Model bermain peran menjadikan peserta didik dapat memahami materi lebih baik lagi, karena peserta didik melakukan pengamatannya sendiri, mengkomunikasikan tujuan pembelajaran, memainkan secara langsung pelajaran menjadi lebih nyata, memberikan peluang untuk lebih mendalami setelah diskusi dan memerankannya lebih baik lagi.

Sikap perbuatan pada pertemuan pertama $60 \%$ pada pertemuan kedua meningkat menjadi $92 \%$, perbuatan dapat diamati saat peserta didik aktif dalam kerja kelompok, membantu teman dalam kelompok yang mengalami kesulitan dalam melakukan percobaan pada saat bermain peran. Meningkatnya minat belajar siswa pada pertemuan kedua dikarenakan siswa sudah memahami cara menggunakan metode role playing, serta siswa diberikan tugas untuk membuat sendiri drama materi peranan virus, sehingga siswa lebih aktif dalam belajar serta bekerja sama dalam kelompok. Menurut Santoso, (2011) bahwa metode role playing dapat Membangkitkan gairah dan semangat optimisme dalam diri siswa serta menumbuhkan rasa kebersamaan dan kesetiakawanan sosial yang tinggi.

Berdasarkan analisis hasil perhitungan dengan rumus uji-t pada pernyataan angket diperoleh harga $t_{\text {hitung }}$ sebesar 11,75 kemudian di cek dengan harga $\mathrm{t}_{\text {tabel }}$ dengan $\mathrm{dk}=(\mathrm{n} 1+\mathrm{n} 2)-2$ dengan taraf signifikan $5 \%$ yaitu sebesar 1,672 setelah dicek ternyata $\mathrm{t}_{\text {hitung }}>\mathrm{t}_{\text {tabel }}$ atau $11,75>1,672$ hal ini menunjukkan bahwa $\mathrm{H}_{0}$ ditolak Ha diterima dan dapat disimpulkan bahwa penggunaan metode Role Playing berpengaruh signifikan terhadap minat belajar siswa kelas X di SMA Azharyah Palembang. Berpengarunya metode Role Playing terhadap minat belajar siswa disebabkan oleh metode Role Playing menjadikan peserta didik terlibat aktif, sehingga pembelajaran tidak didominasi oleh pendidik. Selain itu, metode Role Playing juga memberikan suasana yang menyenangkan, sehingga siswa lebih antusias dalam mengikuti pembelajaran di kelas. Aktifnya siswa dalam suasana yang menyenangkan dalam proses pembelajaran, mengakibatkan pemahaman siswa dalam materi replikasi virus dan peranan virus meningkat sehingga hasil belajar peserta didik meningkat. Seperti dikemukakan Teed (2009) bahawa metode Role Playing dapat memotivasi siswa dan dapat berguna bagi siswa karena mengutamakan sisi kemampuan kecakapan (real-world) dari ilmu pengetahuan.

Berdasarkan penelitian dan uji 
hipotesis yang dibahas diatas, menunjukkan bahwa penggunaan metode Role Playing pada materi virus berpengaruh terhadap minat belajar siswa kelas $\mathrm{X}$ di SMA Azharyah Palembang.

\section{KESIMPULAN}

Berdasarkan hasil penelitian yang penulis lakukan, maka diperoleh kesimpulan bahwa:

1. Dari hasil uji t yang dilakukan di dapat nilai untuk $\mathrm{t}_{\text {hitung }}=11,75$ dan $\mathrm{t}_{\text {tabel }}$ dengan signifikan $5 \%=1,672$ artinya $\mathrm{H}_{0}$ ditolak dan $\mathrm{H}_{\mathrm{a}}$ diterima.

2. Penggunaan metode Role Playing berpengaruh terhadap minat belajar siswa pada materi virus di SMA Azharyah Palembang.

\section{DAFTAR PUSTAKA}

Abdurrahman, M. (2012). Anak berkesulitan belajar. Jakarta: Rineka Cipta

Ahmadi, A., Widodo S. (2013). Psikologi Belajar. Jakarta: Rineka Cipta.

Amilda, Mardiah A. (2012). Kesulitan Belajar: Alternatif Sistem Pelayanan dan Penanganan. Yogyakarta: Pustaka Felicha

Baroro, K. (2011), Upaya Meningkatkan Nilai-nilai Karakter Peserta Didik Melalui Penerapan Metoderole playing. Jakarta: Rineka Cipta

Departemen Agama Republik Indonesia. Al Quran Al-Karim Dan Terjemahan. Semarang: CV Toha Putra

Hamdayama J. (2014). Model dan Model Pembelajaran yang Kreatif dan Berkarakter. Bogor: Ghalia Indonesia

Ramayulis (2002). Metodologi Pendidikan Agama Islam. Jakarta: Kalam Mulia

Teed. R. (2009) Role Playing Excercises.

http://serc.carleton.edu/introgeo/ roleplaying. diakses pada 29 Agustus 2016

Widarti, S., Endah P., Priyantini W.
(2013) Pembelajaran Gallery Walk Berpendekatan Contextual Teaching Learning Materi Sistem Pencernaan di SMA. Unnes Journal of Biology Education, 2 (1). 10-18

Yamin. M. (2005). Strategi Pembelajaran Berbasis Kompetensi. Jakarta: Gaung Persada Prees

Zuhairini. (1983) Ilmu Pendidikan Islam. Jakarta: Rineka Cipta 